Available online at GSC Online Press Directory

GSC Biological and Pharmaceutical Sciences

e-ISSN: 2581-3250, CODEN (USA): GBPSC2

(RESEARCH ARTICLE)

\title{
Purification of antibacterial proteins from Coffee senna (Senna occidentalis) seeds
}

\author{
Adamu Zainab ${ }^{1, *}$, Nzelibe Humphery Chukwuemeka ${ }^{2}$, Inuwa Hajiya Mairo ${ }^{2}$, Yahaya Yunusa Pala ${ }^{3}$ and \\ Abubakar AbdulRahman Umar ${ }^{4}$ \\ ${ }^{1}$ Department of Biochemistry, Federal University of Technology, Minna, Nigeria. \\ ${ }^{2}$ Department of Biochemistry, Ahmadu Bello University, Zaria, Nigeria. \\ ${ }^{3}$ Department of Veterinary Public Health and Preventive Medicine, Ahmadu Bello University, Zaria, Nigeria. \\ ${ }^{4}$ Maternal and Child Hospital, Malumfashi, Katsina, Nigeria.
}

Publication history: Received on 30 April 2019; revised on 20 May 2019; accepted on 22 May 2019

Article DOI: https://doi.org/10.30574/gscbps.2019.7.2.0083

\begin{abstract}
Senna occidentalis (L.) Link formally known as Cassia occidentalis is a popular herb in folk medicine for the treatment of a wide range of microbial infections. Crude, ammonium sulphate precipitated and dialyzed proteins of $S$. occidentalis seeds were evaluated for their antibacterial potential by agar well diffusion and broth dilution techniques, against ten bacterial isolates made up of five Gram positive bacteria; Staphylococcus aureus, Streptococcus pyogenes, Enterococcus Sp, Listeria monocytogene and Bacillus subtilis and five Gram negative bacteria; Escherichia coli, Klebsiella pneumonia, Pseudomonas aeruginosa, Salmonella typhi and Shigella dysentria. The proteins were isolated by gel filtration on sephadex G-75 column and tested for antibacterial activity. The crude, dialyzed and precipitated proteins were active against all Gram positive bacterial isolates tested but were inactive against all Gram negative bacterial isolates used. The Minimum Inhibitory Concentration (MIC) of the crude, precipitated and dialyzed proteins against the most significantly $(\mathrm{p}<0.05)$ sensitive bacterial B. subtilis were $0.67,0.73$ and $3.34 \mathrm{mg} / \mathrm{ml}$ respectively while the Minimum Bactericidal Concentration (MBC) were $2.67,1.46$ and $6.67 \mathrm{mg} / \mathrm{ml}$ respectively. Isolation however, resulted in total loss of antibacterial activities. SDS/PAGE analysis showed that the seed contains different proteins with molecular weights ranging from 14,400 to $66,200 \mathrm{kDa}$. The results of this study suggest that $S$. occidentalis seed contains proteins that have narrow spectrum, synergetic antibacterial activity against important food spoilage bacterial and can therefore be exploited for the development of novel antibacterial agent(s) for food preservation.
\end{abstract}

Keywords: Senna occidentalis; Seeds; Infection; Antibacterial; Proteins; Purification

\section{Introduction}

Bacterial infections are issues of global health concern as they are important causes of morbidity and mortality in developed and developing countries. The current resistance of infectious bacteria to available antibacterial agents has tremendously increased the burden of infectious diseases. This problem is further compounded by low availability of new antibacterial agents in the pipeline as acknowledged by the European Academies Science Advisory Council (EASAC) [EASAC portal, https://www.easac.eu/fileadmin/PDF s/reports statements/Easac statement AntimicrobialDD webvs.pdf, Last accessed on 13/05/2019] and confirmed by the WHO [https://www.who.int/news-room/detail/2009-2017-the-world-is-running-out-of-antibiotics-who-report-confirms and https://www.who.int/ bulletin/volumes/ 89/2/11-030211/en/, Last accessed on 13/05/2019] as well as the British Society for Antimicrobial Chemotherapy Initiative (BSACI) [BSACI portal http://bsac.org.uk/report-of-the-urgent-need-initiative/ Last accessed on $13 / 05 / 2019]$. There is therefore an urgent need for innovative regeneration of antibacterial drug discovery and development.

\footnotetext{
${ }^{*}$ Corresponding author

E-mail address: zainab.adamu@futminna.edu.ng
} 
Like other living organisms, plants have their own fair share of bacterial invasions and are able to produce compounds that act as defence against infectious bacteria [1,2]. Some of these compounds have been identified as proteins that form part of the plant's innate immune system and enable their seeds germinate successfully in the midst of soil bacteria. Although antibacterial proteins are not as crucial for the first line of defence in plants as in animals [3], the search for antibacterial agents with mechanism of actions different from the currently used antibiotics has lead researches to explore antibacterial proteins in plants, not only as a potential replacement for antibiotics, their principle could provide new model for designing novel antibacterial agent [4]. As such, the list of plant bactericidal proteins is being updated continuously.

Additionally, the rise in consumer concern on the deleterious effects of chemical preservatives and the indiscriminate use of antibiotics in animal husbandry has lead to an increasing preference for natural substitutes [5]. Plant derived antibacterial agents have the potential to be used as a replacement for chemical preservatives and antibiotics in food industries and animal husbandry respectively.

Senna occidentalis (L.) Link formally known as Cassia occidentalis, commonly called Coffee Senna, Negro-Coffee, Stinking Weed [6] or Septic Weed is a member of the Senna genus and belongs to the family Fabaceae (also known as Leguminosae). It is a wild flowering plant found in many tropical countries. It is very common in uncultivated farm lands and along road sides in northern Nigeria,

Different parts of $S$. occidentalis plant have been used in folk medicine as an excellent broad-spectrum internal and external antibacterial herb [7]. The seeds are dried, beaten up, and used as coffee substitute. Hence, they are referred to as coffee Senna. Drink prepared from coffee Senna has a reputation for usefulness in the treatment of dermatitis infection, malaria, fevers, kidney and bladder troubles. Despite these uses, there is little research information on the antibacterial activity of $S$. occidentalis seed. Being a leguminous plant, $S$. occidentalis seeds are rich in protein and could be a good source of antibacterial proteins. This research therefore seeks to investigate the protein components of $S$. occidentalis seed as potential antibacterial agent.

\section{Material and methods}

\subsection{Plant collection and identification}

S. occidentalis plants with dried seeds were collected from uncultivated farmland opposite Institute of Agricultural Research, Ahmadu Bello University, Zaria (11009'40.8”N 7038'38.5”E). The plant was identified and authenticated with a voucher of 1611 in the Herbarium of the Department of Biological Science, Ahmadu Bello University, Zaria. The seeds were sorted, air dried and stored in polythene bags until use.

\subsection{Bacterial isolates}

Clinical bacterial isolatesof Staphylococcus aureus; Streptococcus pyogenes; Escherichia coli; Klebsiella pneumoniae; Pseudomonas aeruginosa; Salmonella typhi; and Shigella dysentriae were obtained from the Department of Medical Microbiology, Ahmadu Bello University Teaching Hospital (ABUTH), Zaria, while Enterococcus Sp; Listeria monocytogenes and Bacillus subtilis were obtained from the Department of Veterinary Public Health and Preventive Medicine, Ahmadu Bello University, Zaria. All the bacterial were checked for purity by subculturing on their selective media and incubated for 24 hours, after which they were subcultured on nutrient agar slants and maintained at $4{ }^{\circ} \mathrm{C}$ until use.

\subsection{Extraction of crude protein from $S$. occidentalis seed}

Crude protein was extracted from $S$. occidentalis seed according to the method of Ahmadi et al., [8] with slight modifications. Three grams (3g) of $S$. occidentalis seeds were sterilized by exposure to Ultra Violet light for 15 minutes. The sterile seeds were finely ground and soaked in $30 \mathrm{ml}$ of $50 \mathrm{mM}$ phosphate buffer (pH 7), containing 2mM EDTA, 5\% glycerol and $50 \mathrm{MmNaCl}(1: 10 \mathrm{~W} / \mathrm{V})$. The mixture was shook for two hours at $4{ }^{\circ} \mathrm{C}$ using a mechanical shaker then centrifuged at $10,000 \mathrm{~g}$ for 10 minutes at $4{ }^{\circ} \mathrm{C}$. Total protein content of the supernatant (which contained the crude protein) was determined by measuring absorbance at $280 \mathrm{~nm}$. The crude protein extract was diluted with extraction buffer to $20 \%, 40 \%$ and $60 \% \mathrm{v} / \mathrm{v}$. The protein concentrations, antibacterial activities, MIC and MBC of the diluted crude proteins were determined.

\subsection{Ammonium sulphate precipitation}


Ten mls of the crude protein extract was brought to $80 \%$ ammonium sulphate saturation by gradually adding saturated ammonium sulphate solution at $4{ }^{\circ} \mathrm{C}$ with constant gentle stirring using a magnetic stirrer. Stirring was continued for 2 hours at $4{ }^{\circ} \mathrm{C}$ (after the required saturated ammonium sulphate solution had been added). The mixture was then kept for 12 hours at $4{ }^{\circ} \mathrm{C}$ for complete precipitation to take place. Precipitated proteins were pelleted by centrifugation in a refrigerated centrifuge at $10,000 \mathrm{~g}$ for 10 minutes at $4{ }^{\circ} \mathrm{C}$. The protein precipitate was re-suspended in $5 \mathrm{ml}$ of working buffer ( $50 \mathrm{mM}$ phosphate buffer containing $50 \mathrm{mM} \mathrm{NaCl}$ ). Total protein content of the precipitated protein was determined by measuring absorbance at $280 \mathrm{~nm}$. Protein concentrations, antibacterial activities, MIC and MBC of $20 \%$, $40 \%$ and $60 \% \mathrm{v} / \mathrm{v}$ of the precipitated proteins were determined.

\subsection{Dialysis of precipitated protein}

The precipitated protein $(10 \mathrm{ml})$ was extensively dialyzed against $4 \mathrm{~L}$ of working buffer $(50 \mathrm{mM}$ phosphate buffer containing $50 \mathrm{mM} \mathrm{NaCl} \mathrm{pH} \mathrm{7)} \mathrm{for} \mathrm{a} \mathrm{total} \mathrm{of} 20$ hours using a dialysis bag of $8 \mathrm{kDa}$ molecular weight cut-off. The precipitated protein was first dialyzed against $1 \mathrm{~L}$ of working buffer for 2 hours at $4^{\circ} \mathrm{C}$. The buffer was changed and dialysis was continued with a fresh $1 \mathrm{~L}$ of the working buffer for another 2 hours at $4{ }^{\circ} \mathrm{C}$. The buffer was changed again and dialysis continued overnight ( 12 hours) at $4^{\circ} \mathrm{C}$. The dialyzed protein was centrifuged at 10,000 g for 5 minutes at 4 ${ }^{\circ} \mathrm{C}$ to remove unwanted particles.

Total protein content of the dialyzed protein was determined by measuring absorbance at $280 \mathrm{~nm}$. Protein concentrations, antibacterial activities, MIC and MBC of $20 \%, 40 \%$ and $60 \% \mathrm{v} / \mathrm{v}$ of the dialyzed proteins were determined.

\subsection{Sephadex G-75 gel filtration}

After dialysis, $200 \mu \mathrm{L}$ of the sample was fractionated on a $1.5 \mathrm{~cm} \times 50 \mathrm{~cm}$ Sephadex G-75 column that had been equilibrated with $50 \mathrm{mM}$ phosphate buffer containing $50 \mathrm{mM} \mathrm{NaCl}, \mathrm{pH} 7.0$. One hundred fractions were collected in 2 $\mathrm{ml}$ aliquots at a flow rate of $12 \mathrm{ml} / \mathrm{h}$. The Protein contents of fractions collected were monitored by measuring their absorbance at $280 \mathrm{~nm}$. The peaks of protein concentrations were tested for antibacterial activity.

\subsection{Sodium Dodecyl Sulphate - Polyacrylamide Gel Electrophoresis (SDS-PAGE)}

SDS-PAGE using 10\% gel strength was conducted. Protein bands were stained with Coomassie blue and visualized under a UV light.

\subsection{Standardization of bacteria}

Bacterial isolates were subcultured on their selective media and incubated for 24 hours. The Bacterial isolates were then inoculated in $10 \mathrm{ml}$ sterile normal saline solution and incubated at $37^{\circ} \mathrm{C}$ for 6 hours. After the incubation period, sterile normal saline solution was added to the growth medium to adjust its turbidity (by visual comparison) to match the turbidity of $0.5 \mathrm{McF}$ arland turbidity standard. This gave an approximate cell density of $1.5 \times 10^{8}$ colony-forming units per millilitre (cfu/ml) of growth medium.

\subsection{Antibacterial activity}

Antibacterial activity was carried out on Muller Hilton Agar by agar well diffusion method as described by Hugo and Rusell [9].Sterile agar plates were prepared and seeded with $0.1 \mathrm{ml}$ of the standardized bacteria. The inoculawere spread evenly over the surface of the agar with a sterile swab. A sterile standard cork borer of $4 \mathrm{~mm}$ diameter was used to bore holes on the inoculated agar plates. One hundred microliter $(100 \mu \mathrm{l})$ of each protein solutions were added separately to the agar wells. Wells containing Extraction buffer instead of protein solutions served as the negative control while Ciprofloxacin and Sparfloxacin standard antibacterial disc placed on the surface of the agar served as the positive control. The inoculated plates were kept at room temperature for one hour to enable the protein solution diffuse across the surface. The plates were then incubated at $37^{\circ} \mathrm{C}$ for 24 hours, after which they were observed for zones of inhibition of bacterial growth around the agar well. The zones were measured with a transparent ruler and results obtained were recorded in millimetre.

\subsection{Minimum Inhibitory Concentration (MIC)}

MIC of the diluted proteins against susceptible bacteria isolates were determined using broth dilution method as described by Egharevba et al., [10] Ten millilitres of $(10 \mathrm{ml})$ of Muller Hilton broth (prepared according to manufacturer's instruction) were dispensed into separate test tubes, sterilized at $121^{\circ} \mathrm{C}$ for 15 minutes and allowed to cool. Isolates of bacteria that were susceptible to the protein solutions were standardized with freshly prepared 0.5 
McFarland's turbidity standard. A concentration of $80 \%, 40 \%$ and $20 \%$ protein in sterile broth were prepared and there protein concentrations were calculated. $0.1 \mathrm{ml}$ of standardized inocula were inoculated into the different concentrations of proteins and incubated at $37^{\circ} \mathrm{C}$ for 24 hours. A test tube containing the protein-broth solution which was not inoculated with bacteria was incubated alongside to serve as negative control. After the incubation, the test tubes were observed for presence of turbidity as an indication of bacterial growth. The lowest concentration of protein in the broth which showed no turbidity in the test tube was recorded as the MIC.

\subsection{Minimum Bactericidal Concentration (MBC)}

MBC of the diluted proteins were carried out as described by Egharevba et al., [10], the content of the MIC test tubes were sub-cultured on nutrient agar plates and incubated at $37^{\circ} \mathrm{C}$ for 24 hours. After the incubation period, the plates were observed for the presence of bacterial colony. Plates with the lowest concentration of extract and without bacterial colonies were recorded as the MBC.

\subsection{Statistical analysis}

All experiments were carried out in three replicates; The Data was analyzed using statistical package for the social sciences (SPSS), version 20. The results were expressed as mean \pm standard deviation (SD). The data was analyzed by analysis of variance (ANOVA). Difference in zone of inhibition were compared using the Duncan Multiple Range Test. P values less than $0.05(\mathrm{P}<0.05)$ were taken as significant.

\section{Results and discussion}

\subsection{Purification of antibacterial proteins and SDS-PAGE analysis}

Proteins of $S$. occidentalis were subjected to ammonium sulphate precipitation, dialysis and gel filtration chromatography. The elution profile of the proteins on Sephadex G-75 presented in figure 1 shows three major peaks of protein concentration. Results of SDS-PAGE analysis (figure 2) shows that the seedis composed of different proteins with molecular weights ranging from $14 \mathrm{kDa}$ to $66 \mathrm{kDa}$.

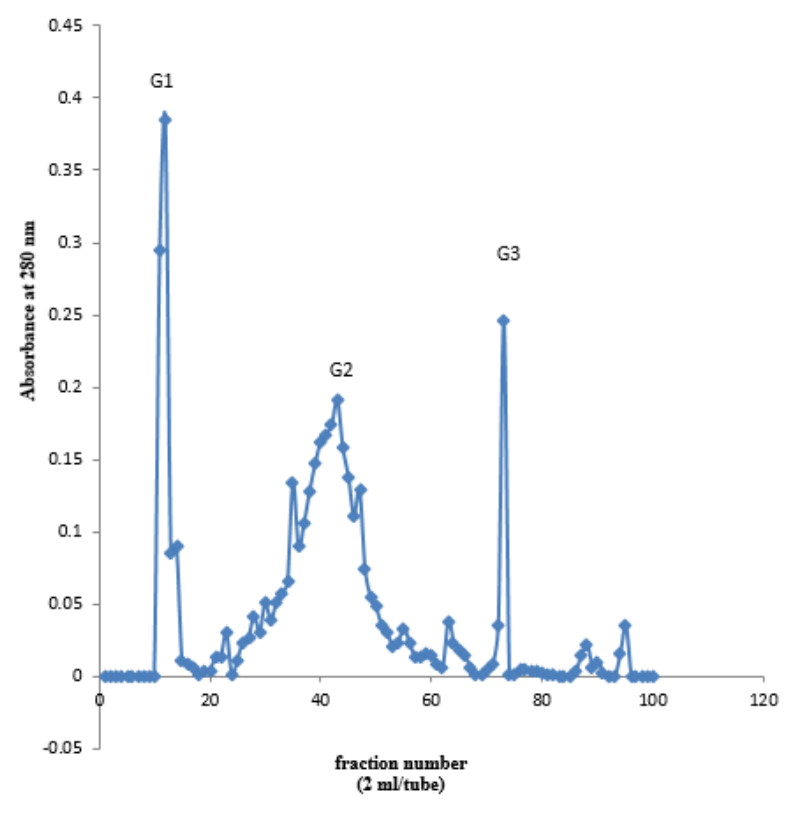

Figure 1 Sephadex G 75 Gel filtration Elution profile for of S. occidentalis seed proteins 


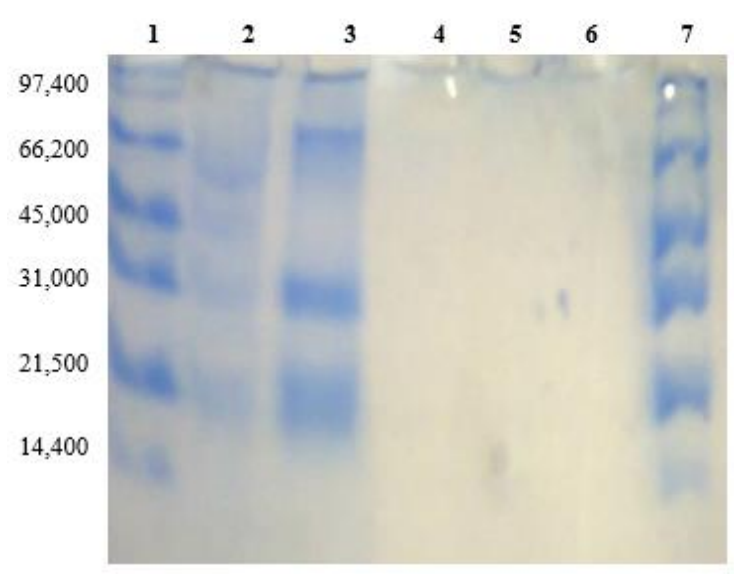

Figure 2 SDS-PAGE analyses of S. occidentalis seed proteins

Lane 1- Molecular weight markers, Lane 2 - Crude protein, Lane-3-Ammonium sulphate (80\%) precipitated protein, Lane-4-Peak G1, Lane-5- Peak G2, Lane-6- Peak G3, Lane-7- molecular weight markers.

\subsection{Antibacterial activities of $S$. occidentalis seed proteins}

Results of antibacterial activity of the crude, precipitated and dialyzed protein extracts of $S$. occidentalis seed are presented in Table 1, while the zones of inhibitions are shown in Figure 3, 4and 5. The crude, precipitated and dialyzed protein extracts at $60 \%$ and $40 \%$ generally exhibited intermediate inhibitory activity against the five Gram positive bacteria according to the clinical and laboratory standards institute [11] standard but show no effect against any of the five Gram negative bacteria used. Amongst the Gram positive bacteria, significantly higher activity $(P<0.05)$ was observed against B. subtilis, L. monocytogenes and S. aureus compared to S. pyogenes and Enterococcus spp. Retention of antibacterial activity of precipitated proteins ensured the protein nature of the antibacterial agent present in the crude extract.

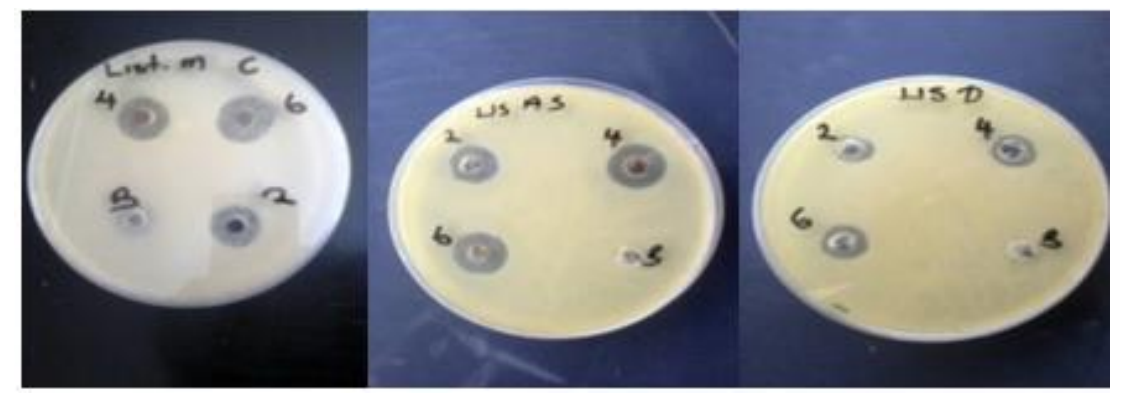

Figure 3 Zones inhibition of L. monocytogenes by 1) Crude protein 2) Precipitated and 3) Dialyzed protein

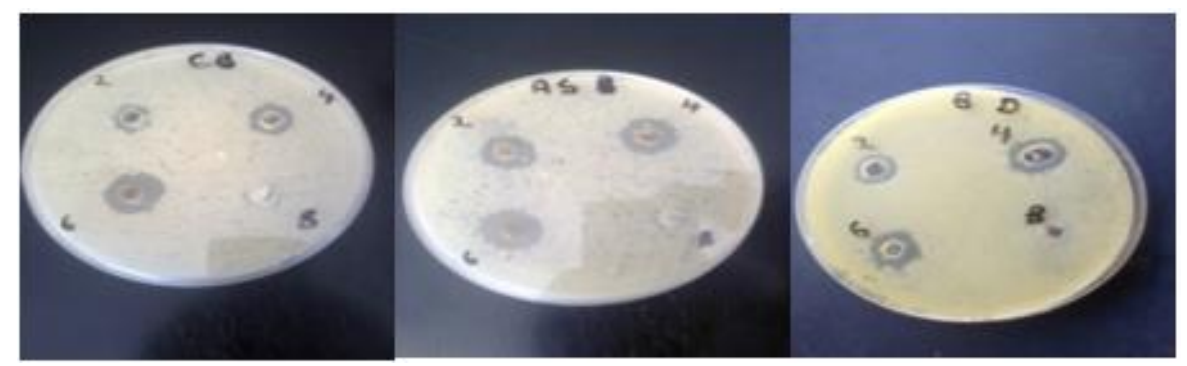

Figure 4 Zones inhibition of B. Subtilis by 1) Crude protein 2) Precipitated and 3) Dialyzed protein 
Adamu et al. / GSC Biological and Pharmaceutical Sciences 2019, 07(02), 118-126

Table 1 Inhibition ( $\mathrm{mm}$ ) of bacteria by crude, precipitated and dialyzed protein extracts of S. occidentalis seed

\begin{tabular}{|c|c|c|c|c|c|c|c|c|c|c|c|}
\hline \multirow[t]{3}{*}{ Sample } & \multirow{3}{*}{$\begin{array}{l}\text { Concentration } \\
\%(\mathrm{mg} / \mathrm{ml})\end{array}$} & \multicolumn{10}{|c|}{ Test organism } \\
\hline & & \multicolumn{5}{|c|}{ Gram positive } & \multicolumn{5}{|c|}{ Gram negative } \\
\hline & & Sa & Bs & Sp & $\mathbf{L m}$ & E Sp & E c & Kp & $\mathbf{P a}$ & St & Sd \\
\hline \multirow[t]{3}{*}{ Crude protein } & $60 \%(9.94)$ & $18.33 \pm 0.58^{\mathrm{b}}$ & $19.00 \pm 0.00^{c}$ & $15.67 \pm 0.58^{\mathrm{a}}$ & $18.00 \pm 0.00^{\mathrm{b}}$ & $16.00 \pm 0.00^{\mathrm{a}}$ & - & - & - & - & - \\
\hline & $40 \%(6.31)$ & $15.00 \pm 0.00^{\mathrm{b}}$ & $16.00 \pm 0.00^{c}$ & $13.00 \pm 0.00^{\mathrm{a}}$ & $16.00 \pm 0.00^{c}$ & $15.67 \pm 0.58^{c}$ & - & - & - & - & - \\
\hline & $20 \%(3.22)$ & $13.67 \pm 0.58^{b}$ & $14.00 \pm 0.00^{\mathrm{b}}$ & $11.00 \pm 1.00^{\mathrm{a}}$ & $13.00 \pm 0.00^{\mathrm{b}}$ & $13.33 \pm 0.58^{b}$ & - & - & - & - & - \\
\hline \multirow{3}{*}{$\begin{array}{l}\text { Precipitated } \\
\text { protein }\end{array}$} & $60 \%(20.2)$ & $18.33 \pm 0.58^{\mathrm{b}}$ & $23.33 \pm 0.58^{\mathrm{d}}$ & $18.00 \pm 0.00^{\mathrm{b}}$ & $22.33 \pm 0.58^{c}$ & $17.00 \pm 0.00^{\mathrm{a}}$ & - & - & - & - & - \\
\hline & $40 \%(13.7)$ & $17.00 \pm 0.00^{\mathrm{b}}$ & $20.33 \pm 0.58^{c}$ & $15.00 \pm 0.00^{\mathrm{a}}$ & $20.00 \pm 0.00^{c}$ & $16.67 \pm 0.58^{\mathrm{b}}$ & - & - & - & - & - \\
\hline & $20 \%(7.32)$ & $16.33 \pm 0.58^{c}$ & $16.00 \pm 0.00^{c}$ & $13.00 \pm 0.00^{\mathrm{a}}$ & $19.33 \pm 0.58^{\mathrm{d}}$ & $14.00 \pm 0.00^{\mathrm{b}}$ & - & - & - & - & - \\
\hline \multirow{3}{*}{$\begin{array}{l}\text { Dialyzed } \\
\text { protein }\end{array}$} & $60 \%(17.5)$ & $18.00 \pm 0.00^{d}$ & $17.00 \pm 0.00^{c}$ & $12.00 \pm 0.00^{\mathrm{a}}$ & $17.00 \pm 0.00^{c}$ & $13.33 \pm 0.58^{\mathrm{b}}$ & - & - & - & - & - \\
\hline & $40 \%(4.05)$ & $12.00 \pm 0.00^{\mathrm{b}}$ & $16.00 \pm 0.00^{\mathrm{d}}$ & $10.00 \pm 0.00^{\mathrm{a}}$ & $15.33 \pm 0.58^{c}$ & $10.00 \pm 0.00 \mathrm{a}$ & - & - & - & - & - \\
\hline & $20 \%(1.90)$ & $10.00 \pm 0.00^{\mathrm{a}}$ & $14.33 \pm 0.58^{c}$ & $9.33 \pm 0.58^{a}$ & $11.67 \pm 0.58^{\mathrm{b}}$ & $9.33 \pm 0.58^{a}$ & - & - & - & - & - \\
\hline
\end{tabular}

S a - Staphylococcus aureus, B s - Bacillus subtilis, S p - Streptococcus pyogenes, L m-Listeria monocytogenes;, E. Sp -Enterococcus spp, E c - Escherichia coli, K p - Klebsiella pneumonia, P a - Pseudomonas aeruginosa, $\mathrm{S} \mathrm{t}$ - Salmonella typhi, S d - Shigella dysentria 


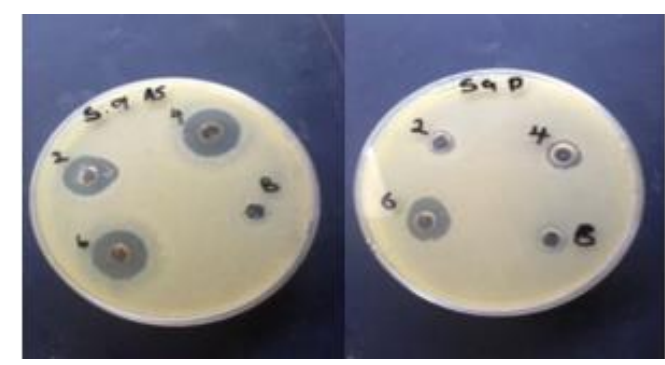

Figure 5 Zones inhibition of S. aureus by 1) Precipitated and 2) Dialyzed protein

Like other antibacterial agents, most plants antibacterial proteins have broad spectrum antibacterial activity. Some, as portrayed in this study are however, specifically inhibitory against Gram positive or Gram negative bacteria [12]. A few examples of antibacterial proteins reported to specifically inhibit Gram positive bacteria linclude; Kalata B2 (a cyclotide) isolated from Oldenlandia affinis [13], Ah-AMP1 isolated from Aesculus hippocastanum[14] as well as Ac-AMP1 and AcAMP2 isolated from Amaranthu scaudatus [15].

The profound unintended collateral damage of broad spectrum antibacterial agent to beneficial gut microbes and their contribution to antibiotic resistance have discouraged their use [16] and have emphasized the importance for narrowspectrum antibacterial agents [17] such as the antibacterial protein identified in this study, which can selectively kill microorganism without affecting non- targeted microbes.

\subsection{Antibacterial activity of isolated proteins}

The isolated proteins of $S$. occidentalis Seed had no activity against any of the bacterial isolates used as shown in Table 2. Loss of antibacterial activity in an attempt to purify the protein could be as a result of interruption of some weak interactions, such as disulfide bridges, that might be essential for antibacterial activity of the protein. A similar observation was made by Kim et al. [18] while purifying a protease inhibitor from potato tubers. The protease inhibitor which inhibited chymotrypsin, trypsin, and papain and also inhibited the growth of Candida albicans, Rhizoctonia solani, and Clavibacter michiganense) was observed to be composed of polypeptide chains joined by disulfide bridges and almost completely lost activity against proteases and fungi when reduced.This indicated that the disulfide bridges are essential for protease inhibition and antimicrobial activities of the protein. Quite a number of antibacterial proteins with more than one sub unit have been reported by other researchers. Kisugi et al. [19] purified a $250 \mathrm{kDa}$ antibacterial glycoprotein consisting of four subunits from Dolabella auricularia and showed both antibacterial and antineoplastic activities. James et al., [20] also isolated a $190 \mathrm{kDa}$ antibacterial protein consisting of more than one subunit from Ciona intestinalis

The antibacterial activity observed in the crude, precipitated and dialyzed protein extract could also be as a result of synergistic actions of two different proteins such that purification of the proteins could cause loss of activity. Kovalskaya and Hammonda [21] reported a pronounced synergistic antibacterial action of a snakin-1(SN1) and a defensin (PTH1) against Pseudomonas syringaepv. syringae and an additive effect against Pseudomonas syringaepv. Tabaci. The report was fully consistent with synergistic and additive antimicrobial effects of both SN1 and PTH1 against phytopathogens previously reported by Segura et al. [22] Additionally, bactericidal activity of Lactococcal Bacteriocin from Lactococcus lactis and plantaricin S from Lactobacillus plantarum were observed by Nissen-Meyer et al., [23] and Jimeet al.,[24] respectively to be dependent on a complementary action of two peptides.

Table 2Antibacterial activity of proteins isolated from $S$. occidentalis seed

\begin{tabular}{llll}
\hline Purification gel & Protein peaks & Concentration $\mathbf{~ m g} / \mathbf{m l}$ & Antibacterial Activity \\
\hline \multirow{3}{*}{ Sephadex G75 } & G1 & 0.356 & $\mathrm{Nil}$ \\
& G2 & 0.194 & $\mathrm{Nil}$ \\
& G3 & 0.251 & $\mathrm{Nil}$ \\
\hline
\end{tabular}

\subsection{MIC and MBC of the crude, precipitated and dialyzed protein}

MIC and MBC of the crude, precipitated and dialyzed protein extracts against susceptible bacterial (S. aureus, B. subtilis and L. Monocytogenes)presented in Table 3 and Table 4 respectively shows that the crude, precipitated and dialyzed 
protein extracts were bactericidal against susceptible bacteria, with $B$. subtilis being the most susceptible bacteria compared to L. monocytogenes and S. aureus.

Table 3 MIC of crude, precipitated and dialyzed protein extracts of S. occidentalis seed

\begin{tabular}{llll}
\hline Samples & \multicolumn{3}{c}{ MIC (mg/ml) of test organism } \\
\cline { 2 - 4 } & Staphylococcus aureus & Bacillus subtilis & Listeria monocytogenes \\
\hline Crude protein & 2.67 & 0.67 & 2.67 \\
precipitated protein & 1.46 & 0.73 & 2.92 \\
Dialyzed protein & 3.34 & 3.34 & 3.34 \\
\hline
\end{tabular}

Table 4 MBC of crude, precipitated and dialyzed protein extracts of S. occidentalis seed

\begin{tabular}{llll}
\hline Samples & MBC $(\mathbf{m g} / \mathbf{m l})$ of test organism & \\
\cline { 2 - 4 } & Staphylococcus aureus & Bacillus subtilis & Listeria monocytogenes \\
\hline Crude protein & 5.33 & 2.67 & 5.33 \\
precipitated protein & 2.92 & 2.92 & 5.83 \\
Dialyzed protein & 6.67 & 6.67 & 6.67 \\
\hline
\end{tabular}

\section{Conclusion}

S. occidentalis seed contains antibacterial protein(s) that are specific against Gram positive bacteria but ineffective against Gram negative bacteria. Toxicity studies of the antibacterial protein(s) of $S$. occidentalis seed is required to establish their safety.

\section{Compliance with ethical standards}

\section{Acknowledgments}

We acknowledge the effort of Dr. Nusrah Afolabi-Balogun; Department of Chemical Sciences Fountain University, Osogbo, Nigeria as well as Dr. Gloria Chechet; Department of Biochemistry, Ahmadu Bello University, Zaria, Nigeria for their assistance.

\section{Disclosure of conflict of interest}

There are no conflicts of interest in connection with this research.

\section{References}

[1] Franco OL, Murad AM, Leite JR, Mendes PA, Prates MV and Bloch CJ. (2006). Identification of a cowpea gammathionin with bactericidal activity. Federation of European Biochemical Societies Journal, 273, 3489-3497.

[2] KovalskayaN, Zhao Y and Hammond RW. (2011). Antibacterial and antifungal activity of a Snakin-Defensin hybrid protein expressed in tobacco and potato plants. The Open Plant Science Journal, 29(42), 1874-2947.

[3] Stotz HU, Waller F and Wang K. (2013). Innate immunity in plants: The role of antimicrobial peptides. In: Hiemstra PS, Zaat SAJ editors. Antimicrobial peptides and innate immunity. USA: Springer; 29-51.

[4] Michael Z. (2002).Review Antimicrobial peptides of multicellular organisms. Nature, 415, 389-395.

[5] Fadaei V. (2012). Milk Proteins-derived antibacterial peptides as novel functional food ingredients. Annals of Biological Research, 3(5), 2520-2526.

[6] Joy PP, Thomas J, Mathew S and Skaria P. (2001). Medicinal plants. Tropical Horticulture vol. 2. Naya Prokash Calcutta India 449-632.

[7] Sadiq IS, Shuaibu M, Bello AB, Tureta SG, Isah A, Izuagie T, and Kamaru MB. (2012). Phytochemistry and antimicrobial activities of Cassia occidentalis used for herbal remedies. Journal of Chemical Engineering, (1)1. 
[8] Ahmadi A, Roghanian R, Emtiazi G and Ghassempour A. (2011). A simple method for primary screening of antibacterial peptides in plant seeds. Iranian Journal of Microbiology 3(2) 104-108.

[9] Hugo WB and Rusell AD. (1992). Pharmaceutical Microbiology, Fifth edition. Blackwell Scientific Publication, Oxford London, 258-297.

[10] Egharevba HO, Odigwe AC, Abdullahi MS, Okwute SK and Okogun JI. (2010). Phytochemical analysis and broad spectrum antimicrobial activity of Cassia occidentalis L. (whole plant) New York Science Journal, 3(10), 74-81.

[11] Clinical and Laboratory Standards Institute. (2012). Performance standards for antimicrobial disk susceptibility tests; approved standard-Eleventh edition 321.

[12] Pelegrini PB, Rafael PS, Osmar NS, Oct'avio LF and Maria FG. (2011). Antibacterial peptides from plants: What they are and how they probably work. Biochemistry Research International 2503499.

[13] Jennings CV, Rosengren KJ and Daly NL. (2005). Isolation, solution structure, and insecticidal activity of kalata B2, a circular protein with a twist: doM"obius strips exist in nature. Biochemistry, 44(3), 851-860.

[14] Fant F, Vranken WF and Borremans FA. (1999).The three dimensional solution structure of Aesculus hippocastanum antimicrobial protein 1 determined by $1 \mathrm{H}$ nuclear magnetic resonance. Proteins, 37(3), 388-403.

[15] Martins JC, Maes D and Loris R. (1996). H NMR study of the solution structure of Ac-AMP2, a sugar binding antimicrobial protein isolated from Amaranthus caudatus. Journal of Molecular Biology, 258(2) 322-333.

[16] Looft T and Allen KH. (2012). Collateral effects of antibiotics on mammalian gut microbiomes. Gut Microbes, (3)5.

[17] Kollef HM. (2008) Broad-spectrum antimicrobials and the treatment of serious bacterial infections: getting it right up front. Clinical Infectious Diseases, 47, 3-13.

[18] Kim JY, Park SC, Kim MH, Lim HT, Park Y and Hahm KS. (2005). Antimicrobial activity studies on a trypsinchymotrypsin protease inhibitor obtained from potato. Biochemical and Biophyical Research Communication, $330,921-927$.

[19] Kisugi J, Ohye H, Kamiya $H$ and Yamazaki M. (1992).Biopolymers from marine invertebrates. XIII. Characterization of an antibacterial protein, dolabellanin A, from the albumen gland of the sea hare, Dolabella auricularia. Chemical and Pharmaceutical Bulletin 40 1537-1539.

[20] James S G, Holmstrom C and Kjelleberg S. (1996). Purification and characterization of a novel antibacterial protein from the marine bacterium D2. Applied Environmental Microbiology, 62, 2783-2788.

[21] Kovalskaya N and Hammonda RW. (2009). Expression and functional characterization of the plant antimicrobial snakin-1and defensin recombinant proteins. Protein Expression and Purification, 63, 12-17.

[22] Segura A, Moreno M, Madueno F, Molina A and Garcia-Olmedo F. (1999). Snakin-1, a peptide from potato that is active against plant pathogens. Molecular Plant Microbe Interactions, 12, 16-23.

[23] Nissen-Meyer J, Helge H, Leiv SH, Knut S and Ingolf FN. (1992). A novel lactococcal bacteriocin whose activity depends on the complementary action of two peptides. Journal of Bacteriology, 174(17), 5686-5692.

[24] Jime NR, Jose L, Ruiz-Barba DP, Cathcart HH, Ingolf FN, Knut HS and Philip JW. (1995). Purification and partial amino acid sequence of plantaricin s, a bacteriocin produced by Lactobacillus plantarum lpco10, the activity of which depends on the complementary action of two peptides Applied Environmental Microbiology 61(12), 4459-4463.

\section{How to cite this article}

Adamu Z, Nzelibe HC, Inuwa HM, Yahaya YP and Abubakar AU. (2019). Purification of antibacterial proteins from Coffee senna (Senna occidentalis) seeds. GSC Biological and Pharmaceutical Sciences, 7(2), 118-126. 